\title{
Electrical Coupling among Irregular-Spiking GABAergic Interneurons Expressing Cannabinoid Receptors
}

\author{
Mario Galarreta, ${ }^{1}$ Ferenc Erdélyi, ${ }^{2}$ Gábor Szabó, ${ }^{2}$ and Shaul Hestrin ${ }^{1}$ \\ ${ }^{1}$ Department of Comparative Medicine, Stanford University School of Medicine, Stanford, California 94305-5342, and ${ }^{2}$ Department of Gene Technology and \\ Developmental Neurobiology, Institute of Experimental Medicine, H-1450, Budapest, Hungary
}

\begin{abstract}
Anatomical studies have shown that the G-protein-coupled cannabinoid receptor-1 $\left(\mathrm{CB}_{1}\right)$ is selectively expressed in a subset of $\mathrm{GABAer}$ gic interneurons. It has been proposed that these cells regulate rhythmic activity and play a key role mediating the cognitive actions of marijuana and endogenous cannabinoids. However, the physiology, anatomy, and synaptic connectivity of neocortical $\mathrm{CB}_{1}$-expressing interneurons remain poorly studied. We identified a population of $\mathrm{CB}_{1}$-expressing interneurons in layer II/III in mouse neocortical slices. These cells were multipolar or bitufted, had a widely extending axon, and exhibited a characteristic pattern of irregular spiking (IS) in response to current injection. $\mathrm{CB}_{1}$-expressing-IS $\left(\mathrm{CB}_{1}-\mathrm{IS}\right)$ cells were inhibitory, establishing $\mathrm{GABA}_{\mathrm{A}}$ receptor-mediated synapses onto pyramidal cells and other $\mathrm{CB}_{1}$-IS cells. Recently, electrical coupling among other classes of cortical interneurons has been shown to contribute to the generation of rhythmic synchronous activity in the neocortex. We therefore tested whether $\mathrm{CB}_{1}$-IS interneurons are interconnected via electrical synapses using paired recordings. We found that $90 \%$ (19 of 21 pairs) of simultaneously recorded pairs of $\mathrm{CB}_{1}$-IS cells were electrically coupled. The average coupling coefficient was $\sim 6 \%$. Signaling through electrical synapses promoted coordinated firing among $\mathrm{CB}_{1}$-IS cells. Together, our results identify a population of electrically coupled $\mathrm{CB}_{1}$-IS GABAergic interneurons in the neocortex that share a unique morphology and a characteristic pattern of irregular spiking in response to current injection. The synaptic interactions of these cells may play an important role mediating the cognitive actions of cannabinoids and regulating coherent neocortical activity.
\end{abstract}

Key words: cannabinoids; $\mathrm{CB}_{1}$; electrical synapses; irregular-spiking; interneuron; GABAergic

\section{Introduction}

$\mathrm{CB}_{1}$ is a G-protein-coupled cannabinoid receptor widely expressed throughout the brain (Matsuda et al., 1990). Cells expressing $\mathrm{CB}_{1}$ receptors are involved in a variety of actions, including regulating rhythmic activity (Hájos et al., 2000), mediating the depolarization-induced suppression of inhibition (DSI) in the hippocampus (Ohno-Shosaku et al., 2001; Wilson and Nicoll, 2001), cerebellum (Kreitzer and Regehr, 2001), and neocortex (Trettel and Levine, 2003; Trettel et al., 2004), and participating in different forms of long-term synaptic plasticity (Gerdeman et al., 2002; Chevaleyre and Castillo, 2003). In the cortical mantle, $\mathrm{CB}_{1}$ receptors are abundantly expressed, showing a particularly dense distribution in superficial layer II/III (Marsicano and Lutz, 1999; Egertova and Elphick, 2000). Although cortical $\mathrm{CB}_{1^{-}}$ expressing interneurons are thought to mediate many of the cognitive actions of marijuana and could play a key role in cortical

\footnotetext{
Received July 23, 2004; revised Sept. 15, 2004; accepted Sept. 16, 2004.

This study was supported by National Institutes of Health Grants EY09120 and EY12114 (S.H.) and National Committee for Technological Development in Hungary Grant 00498/2002 (G.S.). We thank Ken Mackie for the generous gift of the $\mathrm{CB}_{1}$ receptor antibody, Jane Li for her excellent technical work, and Solange Brown for her comments on this manuscript.

Correspondence should be addressed to Dr. Mario Galarreta, Department of Comparative Medicine, Stanford University School of Medicine, 300 Pasteur Drive, Edwards Building R-312, Stanford, CA 94305-5342. E-mail: galarreta@stanford.edu.

DOI:10.1523/JNEUROSCI.3027-04.2004

Copyright $\odot 2004$ Society for Neuroscience $\quad 0270-6474 / 04 / 249770-09 \$ 15.00 / 0$
}

function, very little is yet known about their basic physiology and synaptic connectivity.

Immunohistochemical studies have reported that, in the hippocampus and neocortex, $\mathrm{CB}_{1}$ receptors are present on axon terminals of specific GABAergic cells (Katona et al., 1999; Marsicano and Lutz, 1999; Tsou et al., 1999; Egertova and Elphick, 2000; Bodor et al., 2003). Specifically, $\mathrm{CB}_{1}$ expression has been shown to be mainly restricted to large cells containing the neuropeptide cholecystokinin (CCK) (Katona et al., 1999; Marsicano and Lutz, 1999; Tsou et al., 1999; Bodor et al., 2003). Other major classes of neocortical GABAergic interneurons, including those expressing parvalbumin, somatostatin, or VIP, lack $\mathrm{CB}_{1}$ immunoreactivity (Katona et al., 1999, 2000; Tsou et al., 1999; Bodor et al., 2003). To date, targeting $\mathrm{CB}_{1}$-expressing cells for systematic study has been difficult, and their physiology, morphology, and synaptic properties remain unknown.

Recent studies have demonstrated that several classes of GABAergic interneurons in the cerebral cortex are interconnected via electrical synapses (Galarreta and Hestrin, 1999; Gibson et al., 1999). Cumulative data indicate that gap junctions are established specifically among interneurons belonging to the same type and may define functional classes of GABAergic interneurons (for review, see Galarreta and Hestrin, 2001a; Long and Connors, 2004). Moreover, electrical coupling promotes the coordinated firing of connected cells, contributing to the generation of rhythmic synchronous activity. Neurons expressing $\mathrm{CB}_{1}$ 
A
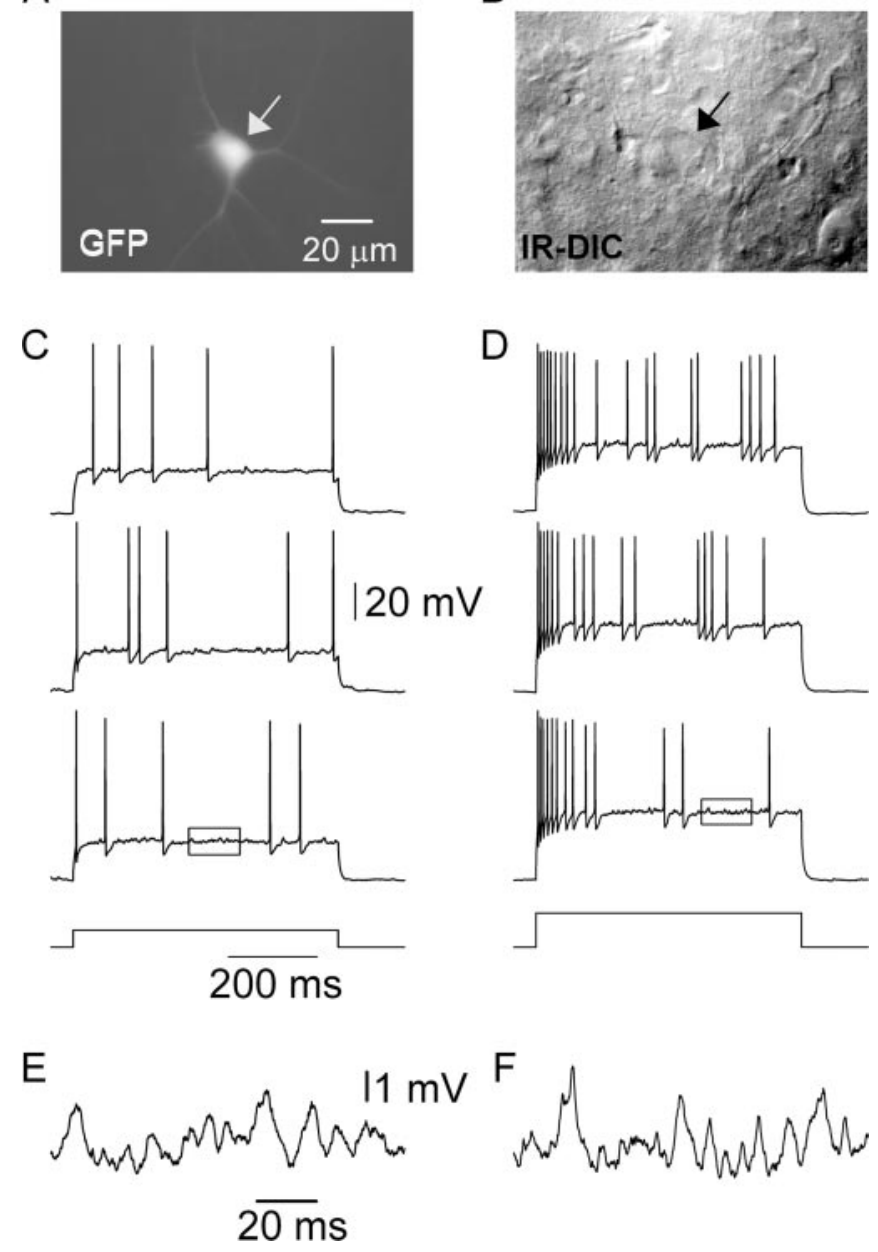

Figure 1. A population of layer II/III GABAergic interneurons is characterized by an irregular pattern of spiking. A, A multipolar EGFP-GAD65 fluorescing cell in a 17-d-old mouse. B, Same field visualized under infrared differential interference contrast (IR-DIC) video microscopy. The arrow points to the cell illustrated in $A$. C, Three examples of the firing pattern of the same neuron in response to a pulse of depolarizing current injection (200 pA, $600 \mathrm{msec})$. Note the characteristic irregular spiking. $D$, Firing pattern in response to a larger current injection (400 $\mathrm{pA}, 600 \mathrm{msec}$ ). E, F, Portions of the bottom traces in ( and $D$ (indicated by the boxes) are shown at an expanded scale to illustrate the oscillations of the membrane potential.

receptors have been proposed to regulate rhythmic oscillatory activity (Hájos et al., 2000; Wilson and Nicoll, 2002), but whether these cells are interconnected via electrical synapses, which may coordinate their firing, remains to be determined.

We have addressed these issues using paired recordings in acute slices of mouse neocortex. We have identified a population of $\mathrm{CB}_{1}$-expressing interneurons in layer II/III with a characteristic morphology and irregular pattern of firing after current injection. $\mathrm{CB}_{1}$-expressing irregular-spiking $\left(\mathrm{CB}_{1}\right.$-IS) cells were inhibitory and established $\mathrm{GABA}_{\mathrm{A}}$ receptor-mediated synapses onto pyramidal cells and other $\mathrm{CB}_{1}$-IS cells. In addition, $\mathrm{CB}_{1}$-IS cells were electrically coupled, and these electrical synapses helped synchronize their firing activity.

\section{Materials and Methods}

Slice preparation and cell identification. We used a mouse strain expressing an enhanced green fluorescent protein (EGFP) under the control of the promoter for glutamic acid decarboxylase 65 (GAD65) (Erdélyi et al., 2002; Brager et al., 2003; López-Bendito et al., 2004). Juvenile mice of both sexes (14-20 d old) were anesthetized by an intraperitoneal injec-
A
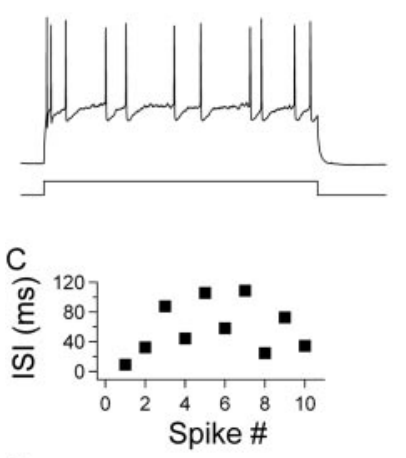

E

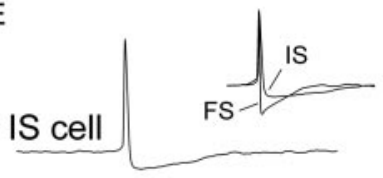

B
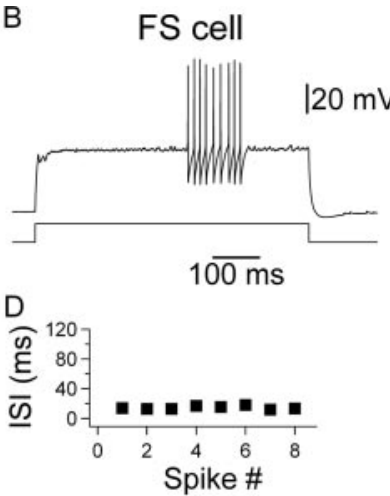

$\mathrm{F}$

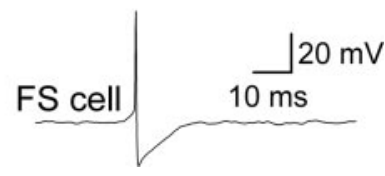

Figure2. Firing properties in IS cells differ from those in FS cells. A, Irregular firing of an IS cell in layer II/III in response to a pulse of depolarizing current ( $400 \mathrm{pA}, 600 \mathrm{msec}) . B$, A typical discharge of high-frequency nonaccommodating action potentials in an $\mathrm{FS}$ cell in response to a near-threshold current injection ( $525 \mathrm{pA}, 600 \mathrm{msec}$ ). C, D, Plot of the interspike intervals for the traces shown in $A$ and $B$, respectively. $E$, Example of an IS cell action potential. $F$, Example of an FS cell action potential. The IS and FS spikes are superimposed in the inset in $E$. Note that the IS spike is wider than that of the FS cell. Also note that the AHP is smaller and slower in the IS cell than in the $F S$ cell. Calibrations in $B$ and $F$ apply to $A$ and $E$, respectively.

tion of ketamine $(87 \mathrm{mg} / \mathrm{kg})$ and xylazine $(13 \mathrm{mg} / \mathrm{kg})$ and were decapitated. Parasagittal cortical slices ( $300 \mu \mathrm{m}$ thick, $30^{\circ}$ angle) were obtained in an ice-cold extracellular solution. After dissection, the slices were incubated at $32-34^{\circ} \mathrm{C}$ for $30 \mathrm{~min}$ and then at room temperature $\left(20-22^{\circ} \mathrm{C}\right)$ until transferred to a submersion-type recording chamber. The extracellular solution bathing the slices during the dissection, incubation, and recordings contained (in mM) $125 \mathrm{NaCl}, 2.5 \mathrm{KCl}, 1.25 \mathrm{NaH}_{2} \mathrm{PO}_{4}, 1$ $\mathrm{MgSO}_{4}, 2 \mathrm{CaCl}_{2}, 26 \mathrm{NaHCO}_{3}, 20$ glucose, 4 lactic acid, 2 pyruvic acid, and 0.4 ascorbic acid, $\mathrm{pH} 7.4(315 \mathrm{mOsm})$ and was continuously bubbled with a gas mixture of $95 \% \mathrm{O}_{2}$ and $5 \% \mathrm{CO}_{2}$. Kynurenic acid (1 mM) was added during the dissection and incubation period.

Fluorescent neurons in the somatosensory cortex were visualized using an upright microscope (Axioskop; Zeiss, Thornwood, NY) illuminated with a xenon lamp (150 W; Opti Quip, Highland Mills, NY) and equipped with a $40 \times$ water immersion lens and EGFP filters (XF100; Omega Optical, Brattleboro, VT). Once a fluorescent neuron was selected, it was visualized using infrared differential interference contrast video microscopy and recorded using conventional patch-clamp techniques (Stuart et al., 1993). EGFP-positive cells were classified as $\mathrm{CB}_{1}$-IS cells depending on their pattern of spiking in response to current injection. Fast-spiking (FS) cells were EGFP negative and were identified by their typical discharges of high-frequency nonaccommodating spikes in response to near-threshold current injection (Kawaguchi and Kubota, 1997). Layer II/III pyramidal cells were selected on the basis of their characteristic dendrosomatic appearance and regular spiking pattern of firing (McCormick et al., 1985).

Paired recording and data analysis. Simultaneous somatic whole-cell recordings were made with patch electrodes (3-4 M $\Omega$ ) filled with a solution containing the following (in $\mathrm{mm}$ ): $130 \mathrm{~K}$-methylsulfate, $6.3 \mathrm{KCl}$, 10 HEPES, 4 MgATP, 20 phosphocreatine(Na), 0.3 NaGTP, 0.2 EGTA and $0.3 \%$ biocytin or $106 \mathrm{~K}$-methylsulfate, $40 \mathrm{KCl}, 10 \mathrm{HEPES}, 4 \mathrm{MgATP}$, 20 phosphocreatine $(\mathrm{Na}), 0.3 \mathrm{NaGTP}, 0.2$ EGTA, and $0.3 \%$ biocytin, $\mathrm{pH}$ 7.3 (295 mOsm). Recordings were performed at $31-32^{\circ} \mathrm{C}$. The error attributable to the liquid junction potential $(-11 \mathrm{mV})$ was not corrected. We did not compensate for the series resistance that ranged between 10 and $25 \mathrm{M} \Omega$. Both cells were recorded under current-clamp mode using two Axopatch 200B amplifiers (Axon Instruments, Union City, CA). The voltage and current output were filtered at $5 \mathrm{kHz}$ and digitized at 16 bit 
resolution (ITC-18; InstruTech, Port Washington, NY), with a sampling frequency of $10 \mathrm{kHz}$.

IPSPs were recorded in the presence of the AMPA and kainate receptor antagonist DNQX (10 $\mu \mathrm{m}$, Sigma, St. Louis, MO). DNQX, bicuculline methiodide (Sigma), WIN55,212-2 (Tocris Cookson, Ellisville, MO), and AM-251 (Tocris Cookson) were applied in the bath. WIN55,212-2 and AM-251 were dissolved in DMSO (10 mM stock solution).

The input resistance and membrane time constant of $\mathrm{CB}_{1}$-IS cells were calculated by injecting long pulses of depolarizing current ( $50 \mathrm{pA}, 300$ msec). Spike amplitudes and the afterhyperpolarization potentials (AHPs) were measured relative to the spike threshold. The strength of the electrical coupling in pairs of $\mathrm{CB}_{1}$-IS cells is reported as the mean of the coupling coefficient from cell 1 to cell 2 and that measured from cell 2 to cell 1 . The coupling coefficient was calculated as the ratio between the change of membrane voltage produced in the noninjected cell and that in the injected cell. Assuming a simple model of two isopotential neurons connected by a single electrical junction, the gap junction conductance (Gc) was calculated according to the equation $\mathrm{Gc}=1 /\left[\left(R_{\mathrm{in} 2} / \mathrm{CC}\right)-\right.$ $R_{\mathrm{in} 2}$ ], where $R_{\mathrm{in} 2}$ is the input resistance of the postsynaptic neuron, and $\mathrm{CC}$ is the step coupling coefficient.

Data are given as mean \pm SEM. Differences were considered statistically significant (Student's $t$ test) if $p<0.05$.

Histology, immunohistochemistry, and morphology. To study the morphology of the recorded neurons, biocytin $(0.3 \%)$ was included in the pipette solution during the physiological experiments. The slices containing biocytin-filled cells were fixed with $4 \%$ paraformaldehyde in 0.01 $\mathrm{M}$ phosphate buffer and $0.2 \%$ picric acid overnight at $4^{\circ} \mathrm{C}$. Standard avidin-biotin-horseradish peroxidase complex (ABC; Vector Laboratories, Burlingame, $\mathrm{CA}$ ) and the 3,3'-diaminobenzidine (DAB) reaction procedure were used. The slices were mounted in M01 media from Biomeda (Foster City, CA). Reconstructions of the neurons were done with Neurolucida (MicroBrightField, Willinston, VT) using a $100 \times$ oilimmersion objective.

To detect the presence of $\mathrm{CB}_{1}$ receptors and parvalbumin in biocytinfilled electrophysiological characterized neurons, the slices were fixed in $4 \%$ paraformaldehyde in $0.01 \mathrm{~m}$ phosphate buffer and $0.2 \%$ picric acid for $2 \mathrm{hr}$ at $4^{\circ} \mathrm{C}$. After washing the slices with Tris-buffered saline (TBS), tissue sections were incubated overnight at $4^{\circ} \mathrm{C}$ with a rabbit anti- $\mathrm{CB}_{1}$ antibody (1:2000; Ken Mackie, Department of Anesthesiology, University of Washington, Seattle, WA). Next, the slices were washed again in TBS and incubated for $3 \mathrm{hr}$ in the secondary antibody goat anti-rabbit IgG Alexa Fluor 555 (1:500; catalog \#A21428; Molecular Probes, Eugene, OR). After rinsing the tissue in TBS, the slices were incubated in streptavidin-Alexa Fluor 350 (1:300; catalog \#S-11249; Molecular Probes) for $45 \mathrm{~min}$ to reveal the biocytin. The slices were rinsed again in TBS and mounted in M01. Those slices tested for parvalbumin were rinsed in TBS, incubated in a blocking solution containing $1 \%$ Triton X-100, $2 \%$ goat serum, and $2 \%$ bovine serum albumin for $4 \mathrm{hr}$, and incubated overnight at $4^{\circ} \mathrm{C}$ with a rabbit anti-parvalbumin antibody (1:3000; catalog \#PV28; Swant, Bellinzona, Switzerland). Next, the slices were rinsed again in TBS and incubated for $3 \mathrm{hr}$ in the secondary antibody goat anti-rabbit IgG Alexa Fluor 555 (1:500; catalog \#A21428; Molecular Probes), rinsed again, and mounted in M01 media.

\section{Results}

Physiology of IS cells

To target $\mathrm{CB}_{1}$-expressing neurons in neocortical slices, we used a line of transgenic mice in which the EGFP-expressing cells include most of the CCK-positive neurons (López-Bendito et al., 2004). Because large, but not small, CCK-containing cells express $\mathrm{CB}_{1}$ receptors (Bodor et al., 2003), we selected large EGFP-positive cells in upper layer II/III for our recordings (Fig. 1A). Cells were visualized under infrared video microscopy (Fig. $1 B$ ) and recorded using conventional patch-clamp techniques. We selected relatively large neurons with multipolar or bitufted appearance. Using this approach, we identified a population of neurons with a characteristic pattern of irregular spiking in response to depolarizing current injections that we termed IS cells. In response to near-threshold cur- rent injections, IS cells typically produced a small number of action potentials with variable interspike intervals (ISIs) (Figs. 1C, 2A). When the same current injection was repeated, the responses were highly variable from trial to trial (Fig. 1C). When larger current injections were used, the spiking was characterized by an initial burst of high-frequency action potentials, followed by a variable number of spikes at irregular interspike intervals (Fig. 1D). The average coefficient of variation of the ISI in traces containing 10 or more spikes was $0.58 \pm 0.05$ ( $n=21$ cells) (Fig. $2 C)$. Other observations among
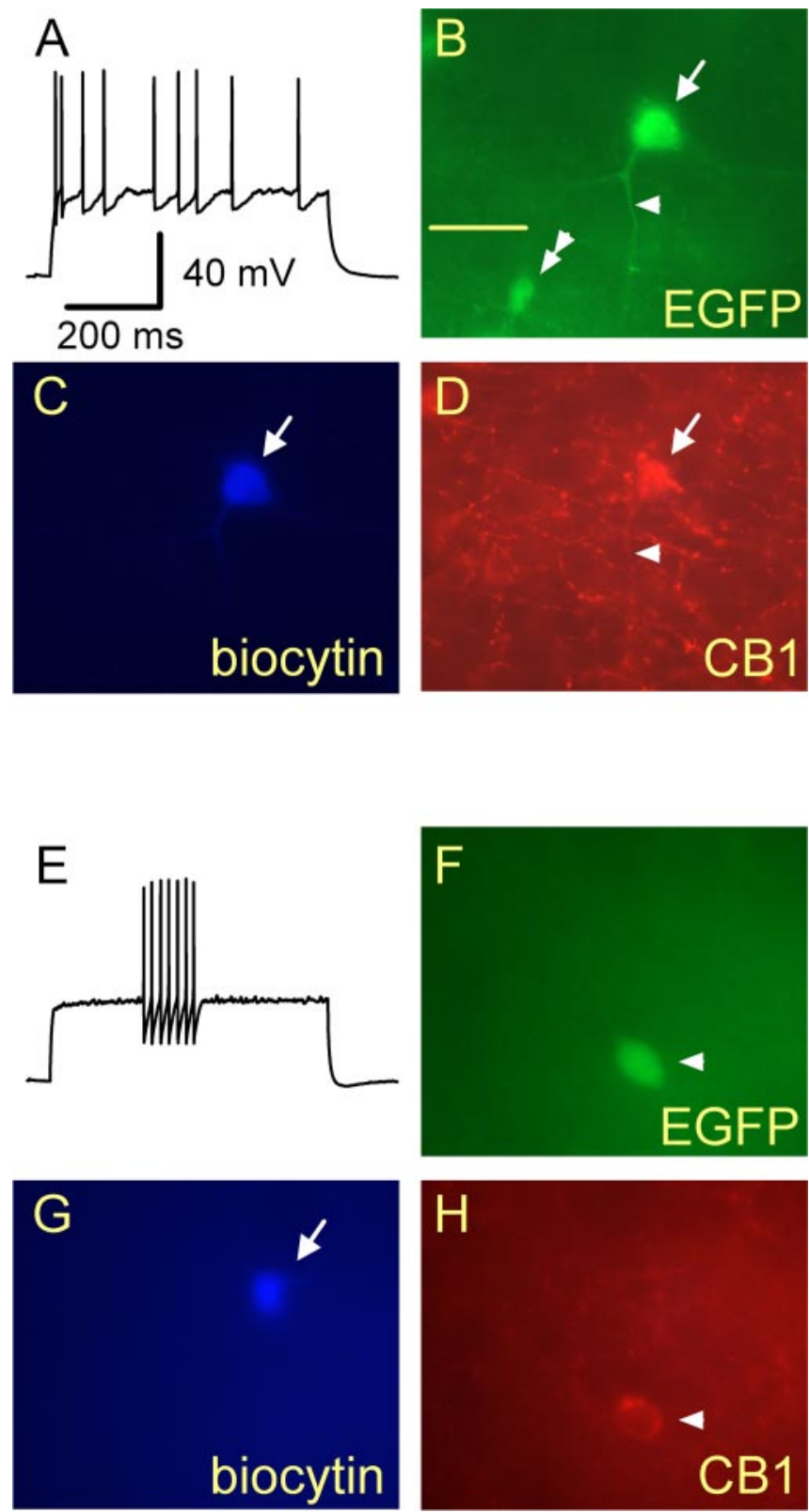

Figure 3. IS cells are immunoreactive to $C B_{1}$ receptors. $A$, Characteristic irregular spiking of a layer II/III neuron. $B$, EGFP fluorescence of the cell whose response is shown in $A$ (arrow). The arrowhead points to the axon of this neuron. The double arrowhead points to an unidentified EGFP-positive- $C B_{1}$-negative cell. $C$, Photograph of the recorded cell filled with biocytin and revealed with streptavidin-Alexa Fluor 350.D, $C_{1}$ immunoreactivity of the cell shown in $A-C$ (arrow). The immunoreactive axon is indicated by the arrowhead. Note the dense network of immunoreactive fibers in layer II/III. Scale bar, $25 \mu \mathrm{m}$ (applies to all images). E, F, FS cells lack $\mathrm{CB}_{1}$ immunoreactivity. $E$, Pattern of firing of a representative FS cell filled with biocytin $(G)$ during the recording (arrow). This cell was EGFP negative $(F)$ and did not show immunoreactivity for $\mathrm{CB}_{1}$ receptors $(H)$. The arrowheads in $F$ and $H$ point to a nonrecorded EGFP-positive cell immunoreactive for $C B_{1}$ receptors. 


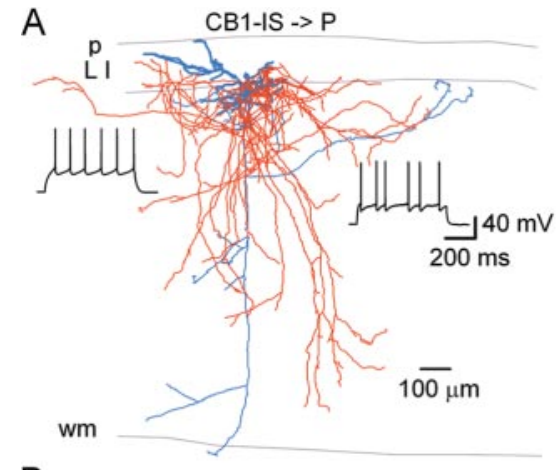

\section{B}

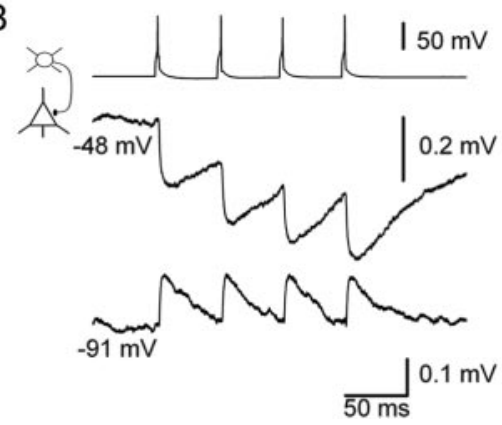

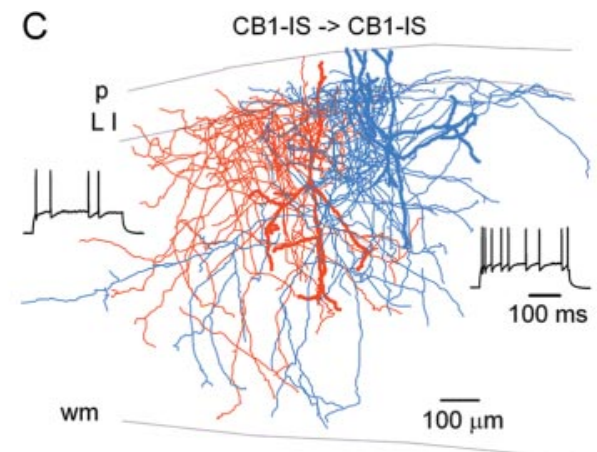

D

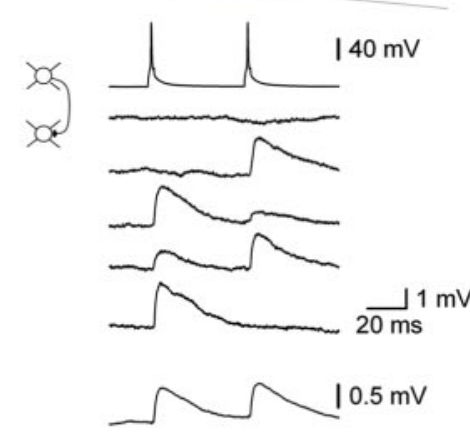

Figure 4. $\quad C_{1}-I S$ cells are $G A B A$ ergic. $A$, Morphological reconstruction of a pair consisting of a presynaptic $C B_{1}-I S$ cell (red) and a postsynaptic pyramidal cell (blue; $(B 1-I S \rightarrow P$ ). Dendrites, Thick lines; axons, thin lines. The insets show the firing of both cells in response to a pulse of depolarizing current. p, Piamater; LI, layer I; wm, white mater. B, Paired recording from the two cells illustrated in $A$. The postsynaptic membrane of the pyramidal cell was either depolarized $(-48 \mathrm{mV})$ or hyperpolarized $(-91 \mathrm{mV})$ $\left(\left[\mathrm{Cl}^{-}\right]_{\mathrm{i}}=6.3 \mathrm{~mm}\right)$. Traces are the average of 80 responses. C, Morphological reconstruction of two synaptically connected $C_{1}-1 S$ cells (CB1-IS $\rightarrow$ CB1-IS). The presynaptic cell is in red, and the postsynaptic cell is in blue. Dendrites, Thick lines; axons, thin lines. The insets show examples of their characteristic irregular spiking in response to pulses of current injection. D, Paired recording from the two $\mathrm{CB}_{1}-\mathrm{IS}$ cells illustrated in C. Two action potentials separated by $50 \mathrm{msec}$ were generated in the presynaptic cell (top trace). Five individual postsynaptic responses recorded at $-78 \mathrm{mV}\left(\left[\mathrm{Cl}^{-}\right]_{\mathrm{i}}=40 \mathrm{~mm}\right.$; middle traces). Note the variability in the amplitude of the postsynaptic responses (coefficient of variation, 0.81 ). Bottom trace, Average of 50 responses. The paired-pulse ratio (IPSP2/IPSP1) was 0.94. The decay of the average IPSP was fitted with an exponential function with a time constant of 21 msec.

IS cells were a reduction in the amplitude of the later spikes in the response (Fig. 1D) and small oscillations of the membrane potential between the spikes (Fig. 1E,F). IS cells had an average input resistance of $127.7 \pm 7.2 \mathrm{M} \Omega$ and a time constant of $12.2 \pm 1.0 \mathrm{msec}(n=$ 21 cells). Their spikes had an average amplitude of $67.4 \pm 1.9 \mathrm{mV}$, a half-width of $0.80 \pm 0.05 \mathrm{msec}$, and were followed by an AHP with an amplitude of $13.5 \pm 0.5 \mathrm{mV}$ and a decay of $55.8 \pm 5.2 \mathrm{msec}$ (Fig. $2 A, E)$. The minimum value of the AHP occurred on average $7.1 \pm$ $0.8 \mathrm{msec}$ after the spike peak (Fig. $2 E$ ). Figure 2 compares the firing pattern and the properties of individual spikes in IS (Fig. $2 A, C, E$ ) and in FS (Fig. $2 B, D, F$ ) cells. Typically, action potentials in IS cells were wider and exhibited smaller, slower AHPs than those described in FS cells (Kawaguchi, 1993, 1995; Galarreta and Hestrin, 2002).

\section{Expression of $\mathrm{CB}_{1}$ receptors}

Next, we determined whether IS cells express $\mathrm{CB}_{1}$ receptors. $\mathrm{CB}_{1}$ immunostaining revealed a dense network of immunopositive fibers in layer II/III, with some scattered immunoreactive somata. We found that 78\% (7 of 9) of physiologically characterized IS cells reacted to the $\mathrm{CB}_{1}$ antibody (Fig. $3 A-D$ ). Immunoreactivity was located in the cell body, with a perinuclear distribution, and also in the axonal process. Some putative boutons of the $\mathrm{CB}_{1}$-positive axonal processes surrounded the cell bodies of $\mathrm{CB}_{1}$ negative cells. Other types of GABAergic interneurons, including the parvalbumin-positive cells, have been shown to be $\mathrm{CB}_{1}$ immunonegative (Katona et al., 1999; Tsou et al., 1999). Consistent with these results, $\mathrm{CB}_{1}$-IS cells were immunonegative for parval-

bumin (data not shown). Furthermore, we recorded from layer II/III FS cells $(n=5)$, known to contain parvalbumin, and found that none of the tested cells were immunopositive for $\mathrm{CB}_{1}$ receptors (Fig. $3 E-H$ ). These results suggest that IS cells express $\mathrm{CB}_{1}$ receptors, and, hereinafter, we will refer to this neuronal population as $\mathrm{CB}_{1}$-IS cells.

\section{Morphology of $\mathrm{CB}_{1}$-IS cells}

To study the morphology of layer II/III $\mathrm{CB}_{1}$-IS cells, we reconstructed electrophysiologically identified neurons filled with biocytin ( $n=14$ cells) (Figs. $4 A, C$, $5 A$ ). Typically the somatodendritic morphology of these cells was either multipolar (polygonal-shaped soma with four or more radial dendrites) or bitufted (ovoidshaped soma with multiple dendrites extending from the upper and lower poles). They had relatively large cell bodies, with average somatic horizontal and vertical diameters of $12.6 \pm 0.4$ and $17.5 \pm 0.7 \mu \mathrm{m}$, respectively ( $n=30$ cells). Their dendrites were smooth (aspiny) and extended radially into layers I, II/III, IV, and V. The total average horizontal and vertical spreads of the dendrites were $360 \pm 40$ and $315 \pm 35$ $\mu \mathrm{m}$, respectively $(n=7)$. In most cases, the axon originated from the lower region of the cell body or from a primary dendrite. Typically, the axon branched profusely in the vicinity of the soma within layer II/III and extended horizontally for several hundred micrometers. In contrast to the dendrites that often extended into layer I and approached the piamater, the axons of $\mathrm{CB}_{1}$-IS cells branched densely in upper layer II but only rarely extended into layer I. In addition, some axonal collaterals descended vertically or obliquely spanning occasionally the entire thickness of the neocortex and reaching layer VI. The total average horizontal and vertical spreads of the axonal arbor were $1085 \pm 170$ and $920 \pm 115 \mu \mathrm{m}$, respectively. We observed some putative axonal boutons surrounding the somata of other cells, suggesting that $\mathrm{CB}_{1}$-IS cells include basket cells. $\mathrm{CB}_{1}$-IS cells are therefore characterized by radial dendrites and a wide axonal arborization that expands horizontally over several hundred of micrometers and spans multiple layers from upper layer II to layer VI.

\section{$\mathrm{CB}_{1}$-IS cells are GABAergic}

To confirm that $\mathrm{CB}_{1}$-IS cells establish GABAergic synapses, we performed simultaneous whole-cell recordings among $\mathrm{CB}_{1}$-IS cells and between $\mathrm{CB}_{1}$-IS cells and layer II/III pyramidal neurons ( $n=65$ pairs). We found nine pairs in which a presynaptic $\mathrm{CB}_{1}$-IS cell was connected via chemical synapses to a pyramidal cell ( $n=5$ of 44 pairs) (Fig. $4 A, B)$ or to another $\mathrm{CB}_{1}$-IS cell $(n=$ 4 of 21 pairs) (Fig. $4 C, D$ ). Anatomical reconstructions of two of these pairs are shown in Figure $4, A$ and $C$. Note that the axons of the $\mathrm{CB}_{1}$-IS cells branched profusely in layer II/III, as well as projected descending branches into layer V and VI. We generated presynaptic action potentials with brief (2-3 msec) suprathreshold current injections in the $\mathrm{CB}_{1}$-IS cells and recorded the 

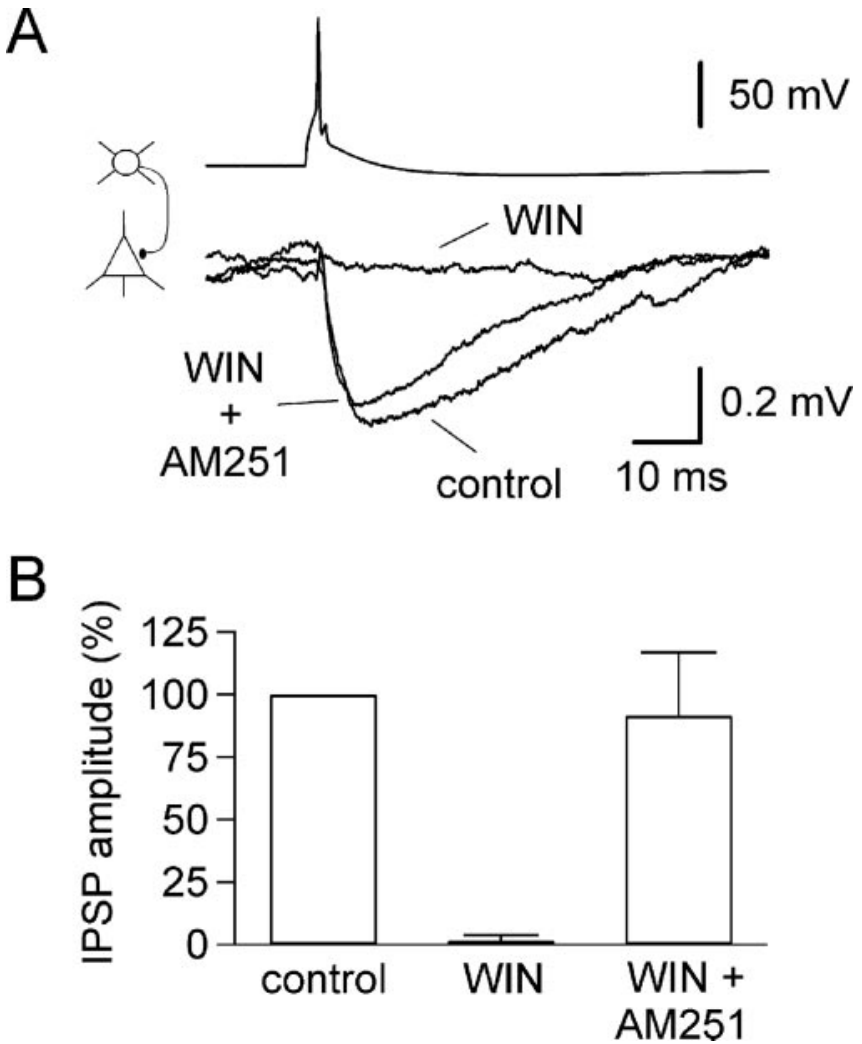

Figure 5. $\quad C_{1}$ receptor activation blocks IPSPs produced by $C_{1}-1 S$ cell onto pyramidal cells. $A$, Paired recording between a presynaptic $C_{1}-1 S$ cell and a postsynaptic pyramidal neuron $\left(V_{\mathrm{m}}=-55 \mathrm{mV}\right.$ ). A control IPSP (control) was abolished after $5 \mathrm{~min}$ of bath application of the cannabinoid receptor agonist WIN55,212-2 (1 $\mu$; WIN). Addition of the $\mathrm{CB}_{1}$ receptor antagonist AM-251 $(10 \mu \mathrm{M})$ reversed the effect of WIN55,212-2. Each trace is the average of $50-75$ trials. $B$, Bar graph summarizing the results obtained in four experiments similar to the one shown in $A$. The amplitude of the response in the presence of WIN55,212-2 was significantly smaller than that of the IPSP recorded in control condition $(p<0.0001)$ and in the presence of $\operatorname{AM-251}(p<0.05)$.

postsynaptic responses at two different potentials (Fig. 4B). As expected for a $\mathrm{GABA}_{\mathrm{A}}$ receptor-mediated response, the synaptic responses were hyperpolarizing when the postsynaptic cell was held at a relatively depolarized potential $\left(V_{\mathrm{m}}=-53 \mathrm{mV},\left[\mathrm{Cl}^{-}\right]_{\mathrm{i}}=\right.$ $6.3 \mathrm{~mm})$. The postsynaptic potentials reversed their polarity and became depolarizing when the postsynaptic cell was kept at -90 $\mathrm{mV}$ (Fig. $4 B$ ). The postsynaptic responses were blocked by the $\mathrm{GABA}_{\mathrm{A}}$ receptor antagonist bicuculline $(10 \mu \mathrm{M})$. Altogether, these results suggest that $\mathrm{CB}_{1}$-IS cells are GABAergic.

Unitary IPSPs evoked by $\mathrm{CB}_{1}$-IS cells onto pyramidal neurons had an average decay time constant of $12.9 \pm 2.5 \mathrm{msec}(n=5$ pairs). The average latency between the peak of the presynaptic spike and that of the postsynaptic inhibitory potential was $4.9 \pm$ $0.3 \mathrm{msec}(n=9$ pairs). Data from the connections onto pyramids $(5.4 \pm 0.2 ; n=5)$ and onto $\mathrm{CB}_{1}$-IS cells $(4.4 \pm 0.6 ; n=4)$ were not statistically different $(p=0.13$ ) and have been pooled together. The amplitude of individual IPSPs generated by $\mathrm{CB}_{1}$-IS cells was highly variable, with an average coefficient of variation of $0.69 \pm 0.06$ (range, $0.40-0.87 ; n=9$ pairs) (Fig. $4 D$ ). We studied short-term plasticity of $\mathrm{CB}_{1}$-IS connections using pairedpulse stimulation with a $50 \mathrm{msec}$ interval. The mean paired-pulse ratio (IPSP2 amp/IPSP1 amp) was $0.92 \pm 0.08$ ( $n=8$ pairs) (Fig. $4 B, D)$. Paired-pulse ratios in IPSPs onto pyramidal cells $(0.89 \pm$ $0.13 ; n=5)$ and $\mathrm{CB}_{1}$-IS cells $(0.97 \pm 0.03 ; n=3)$ were not statistically different $(p=0.69)$.
$\mathrm{CB}_{1}$ receptor activation blocks $\mathrm{CB}_{1}$-IS IPSPs

Activation of $\mathrm{CB}_{1}$ receptors reduces GABA release in GABAergic axonal terminals of the hippocampus (Katona et al., 1999; Hájos et al., 2000; Hoffman and Lupica, 2000) and the neocortex (Trettel and Levine, 2002). GABAergic interneurons are heterogeneous, and only those expressing $\mathrm{CB}_{1}$ receptors are selectively targeted by cannabinoid agonists. Thus, paired recordings have shown that, whereas some unitary IPSCs are dramatically depressed by cannabinoid agonists, others remain unaffected (Ohno-Shosaku et al., 2001; Wilson et al., 2001). To examine whether $\mathrm{CB}_{1}$-IS cells express functional $\mathrm{CB}_{1}$ receptors in their axonal terminals, we tested the effect of the cannabinoid receptor agonist WIN55,212-2 (1 $\mu \mathrm{M})$ on $\mathrm{CB}_{1}$-IS-mediated IPSPs. In all tested pairs $(n=4)$, WIN55,212-2 completely abolished (to $1.6 \pm$ $2.2 \%$ of control) the IPSP generated by a $\mathrm{CB}_{1}$-IS cell onto a pyramidal neuron (Fig. 5). The inhibitory transmission was recovered after the addition of the $\mathrm{CB}_{1}$ selective antagonist AM-251 (10 $\mu \mathrm{M}$; to $91.6 \pm 25.2 \%$ of control). These results indicate, therefore, that $\mathrm{CB}_{1}$-IS cells express functional $\mathrm{CB}_{1}$ receptors whose activation can completely block $\mathrm{CB}_{1}$-IS mediated IPSPs.

\section{Electrical coupling among $\mathrm{CB}_{1}$-IS cells}

Recent studies have shown that interneurons belonging to the same type are electrically coupled via gap junctions (for review, see Galarreta and Hestrin, 2001a; Long and Connors, 2004). To study whether $\mathrm{CB}_{1}$-IS cells are interconnected via electrical synapses, we recorded from pairs of $\mathrm{CB}_{1}$-IS cells in layer II/III (Fig. $6 A, B)$ and injected pulses of subthreshold depolarizing or hyperpolarizing current into one of the cells. The distance between the somata of the two cells ranged from 37 to $218 \mu \mathrm{m}$, with an average value of $106 \pm 16 \mu \mathrm{m}$. When the cells were electrically coupled, we observed a change in the membrane potential of the noninjected cell (Fig. $6 C$ ). We found that $90 \%$ of the pairs examined ( 19 of 21 pairs) were electrically coupled. The mean coupling coefficient was $5.6 \pm 0.8 \%$ (range, $0.6-10.9 \% ; n=19$ pairs) (Fig. $6 D$ ). Electrical coupling was always bidirectional. Furthermore, we observed that, although the strength of the electrical coupling varied significantly among different pairs of $\mathrm{CB}_{1}$-IS cells, it was similar in both directions (Fig. 6D). Assuming a model of isopotential cells, the estimated coupling conductance between pairs of $\mathrm{CB}_{1}$-IS cells was $427 \pm 67 \mathrm{pS}$ (range, 44-941 pS; $n=19$ pairs). Electrical coupling was not found between $\mathrm{CB}_{1}$-IS cells and pyramidal neurons (20 pairs tested).

Next, we studied how action potentials in $\mathrm{CB}_{1}$-IS cells are transmitted through the electrical synapses. We examined this issue in trials in which the presynaptic cell fired spontaneously, after being depolarized to near threshold with a prolonged current injection (Fig. 7A). Individual spikes produced a biphasic signal in the postsynaptic cell. Typically, the hyperpolarizing component reflecting the spike AHP was larger $(0.8 \pm 0.15 \mathrm{mV}$; $n=7$ pairs) and slower than the brief depolarizing component $(0.48 \pm 0.11 \mathrm{mV} ; n=7$ pairs $)$ reflecting the spike itself. The average latency between the peak of the presynaptic spike and that of the postsynaptic spikelet was $0.88 \pm 0.20 \mathrm{msec}$ (range, $0.51-2.03 \mathrm{msec} ; n=7$ pairs) (Fig. $7 C$ ). The hyperpolarizing component reached its minimum $20.90 \pm 1.97 \mathrm{msec}$ after the peak of the presynaptic spike and decayed to baseline over tens of milliseconds (half-width, $49.1 \pm 7.1 \mathrm{msec}$ ) (Fig. 7B). These slow kinetics reflect the relatively slow AHP of $\mathrm{CB}_{1}$-IS cells (Fig. 2).

Electrical synapses promote coordinated firing of $\mathrm{CB}_{1}$-IS cells Electrical coupling has been shown to promote coordinated firing of different classes of GABAergic neocortical interneurons 


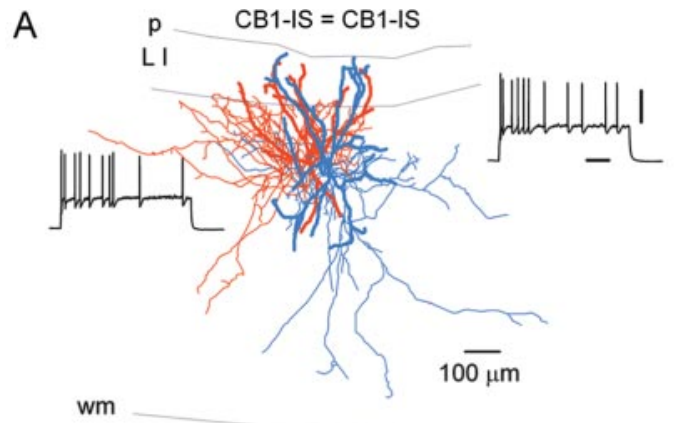

B
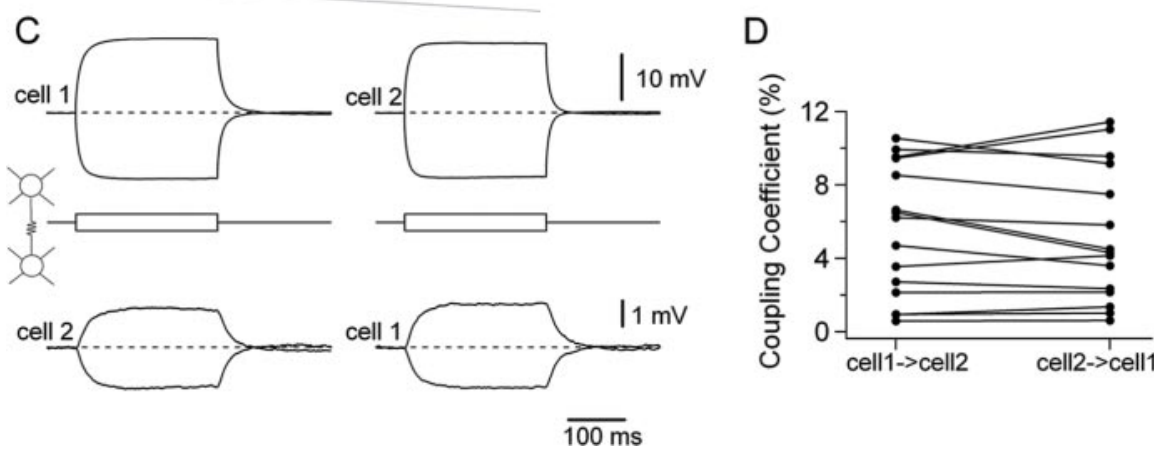

Figure 6. $\quad C B_{1}-I S$ cells are electrically coupled. $A$, Morphological reconstruction of a pair of electrically coupled $C B_{1}-I S$ cells $(C B 1-I S=C B 1-I S)$. Dendrites, Thick lines; axons, thin lines. The insets show the characteristic irregular firing of both cells in response to a pulse of depolarizing current. $p$, Piamater; $L I$, layer I; wm, white mater. $B, D A B$ staining of the $C B_{1}-I S$ cells shown in A. C, Paired recording of the cells illustrated in $A$ and $B$. Left, The injection of depolarizing $(+100 \mathrm{pA})$ or hyperpolarizing $(-100 \mathrm{pA})$ current in cell 1 simultaneously affected the membrane voltage of the noninjected cell 2 . The injection of current in cell 2 similarly affected the membrane potential of cell 1 . The coupling coefficient was $10.2 \%$. Traces are the average of $80-100$ responses. $D$, Bi-directionality of electrical coupling. Plot showing the coupling coefficient when current is transmitted from cell 1 to cell 2 and from cell 2 to cell 1. Data from the same pair are connected by a line.

(Galarreta and Hestrin, 1999; Gibson et al., 1999; Tamás et al., 2000; Deans et al., 2001; Hormuzdi et al., 2001). Having demonstrated the presence of electrical synapses among $\mathrm{CB}_{1}$-IS cells, we next studied whether signaling through electrical synapses could coordinate the spiking activity of $\mathrm{CB}_{1}$-IS cells. We studied whether the generation of a spike in a $\mathrm{CB}_{1}$-IS cell could facilitate the firing of an electrically coupled $\mathrm{CB}_{1}$-IS cell. We recorded simultaneously from pairs of electrically coupled $\mathrm{CB}_{1}$-IS cells and depolarized both cells until they fired at relatively low frequencies with variable interspike intervals (Fig. $8 \mathrm{~A}$ ). The average firing frequency was $10.7 \pm 1.8 \mathrm{~Hz}$ (range, $3.1-18.6 \mathrm{~Hz} ; n=8$ cells in 4 pairs). Under these conditions, we examined whether the firing of both cells was correlated by detecting spikes that occurred within a $5 \mathrm{msec}$ time window in both cells. We defined firing correlation as the fraction of spikes in one cell that occurred within a window of $5 \mathrm{msec}$ from a spike in the second cell, relative to the total number of spikes. We found that a high percentage of spikes $(52.1 \pm 11.6 \%$; range, $25.5-78.0 \% ; n=4$ pairs $)$ were correlated between the two cells (Fig. $8 \mathrm{~A}$, diamonds), suggesting that electrical coupling facilitated the coordinated firing of both cells. The mean coupling coefficient in these four pairs was $8.7 \pm 1.5 \%$. A cross-correlogram of the action potentials evoked in these cells showed a significant increase in firing frequency near $0 \mathrm{msec}$ (Fig. $8 \mathrm{~B}$ ). A closer examination of this increase in firing probability revealed the existence of two peaks offset from 0 and centered at $\pm 1.55 \mathrm{msec}$ (range, $0.9-2.5 \mathrm{msec}$ ) (Fig. $8 \mathrm{~B}$, inset). These peaks reflect the fact that, in some cases, a spike in cell 1 preceded the firing of cell 2, whereas in other cases, the firing of cell 1 followed a spike in cell 2 (Fig. 9A).

Next, we examined in further detail the temporal relationship between coordinated spikes. We observed that typically a spike in one cell produced a spikelet in the second cell that peaked between 0.5 and $1.5 \mathrm{msec}$. If the membrane voltage of the second cell reached the spike threshold during the rise or peak of the spikelet, a spike was then generated in that cell (Fig. 9B). Thus, these data suggest that the electrically transmitted spikelet, together with the rise time of the postsynaptic spike, accounted for the brief delay measured between the peaks of correlated spikes in electrically coupled $\mathrm{CB}_{1}$-IS cells. Altogether, these results suggest that, under these conditions, transmission of spikelets underlies the coordinated firing activity of $\mathrm{CB}_{1}$-IS cells.

\section{Discussion}

In this paper, we identified a population of $\mathrm{CB}_{1}$-expressing GABAergic neurons in the neocortex. These cells are characterized by an irregular pattern of firing after current injection and a widely spread axonal arborization. Furthermore, $\mathrm{CB}_{1}$-IS cells are electrically coupled, forming a network in which electrical synapses promote their coordinated spiking.

The endocannabinoids are lipidsoluble messengers that interact with cell surface receptors that are also activated by $\Delta^{9}$-tetrahydrocannabinol, the principle active component in marijuana (Piomelli, 2003). Endocannabinoids are thought to function as retrograde messengers released by neurons to suppress the strength of their synaptic inputs by activating presynaptic $\mathrm{CB}_{1}$ receptors. In the hippocampus (Ohno-Shosaku et al., 2001; Wilson and Nicoll, 2001), the cerebellum (Kreitzer and Regehr, 2001), and the neocortex (Trettel and Levine, 2003), endocannabinoid activation of $\mathrm{CB}_{1}$ receptors has been shown to mediate DSI, a transient depression of inhibition after the depolarization of the postsynaptic cell (Llano et al., 1991; Pitler and Alger, 1992). Endocannabinoids have also been proposed to regulate rhythmic activity (Hájos et al., 2000) and be involved in some forms of long-term depression (Gerdeman et al., 2002; Chevaleyre and Castillo, 2003). $\mathrm{CB}_{1}$ modulation of synaptic efficacy may have significant functional consequences in the cerebral cortex, and it is therefore important to identify and study the cells containing $\mathrm{CB}_{1}$ receptors. Here we selected and recorded for the first time from a population of interneurons expressing $\mathrm{CB}_{1}$ receptors in the neocortex. The expression of $\mathrm{CB}_{1}$ receptors was detected immunohistochemically and confirmed pharmacologically. $\mathrm{GABA}_{\mathrm{A}}$-mediated synaptic responses generated by $\mathrm{CB}_{1}$-IS cells onto pyramidal neurons were blocked by a cannabinoid agonist, and this effect was reversed by a selective $\mathrm{CB}_{1}$ receptor antagonist. $\mathrm{CB}_{1}$-IS cells were characterized by an irregular pattern of spiking in response to depolarizing current injection and a unique morphology.

$\mathrm{CB}_{1}$-IS cells exhibited a characteristically irregular pattern of firing different from those previously identified as fast spiking, late spiking, and low-threshold spiking (LTS)/burst-spiking nonpyramidal cells (Kawaguchi and Kubota, 1997). Irregular firing similar to the one we describe here has been observed in a popu- 

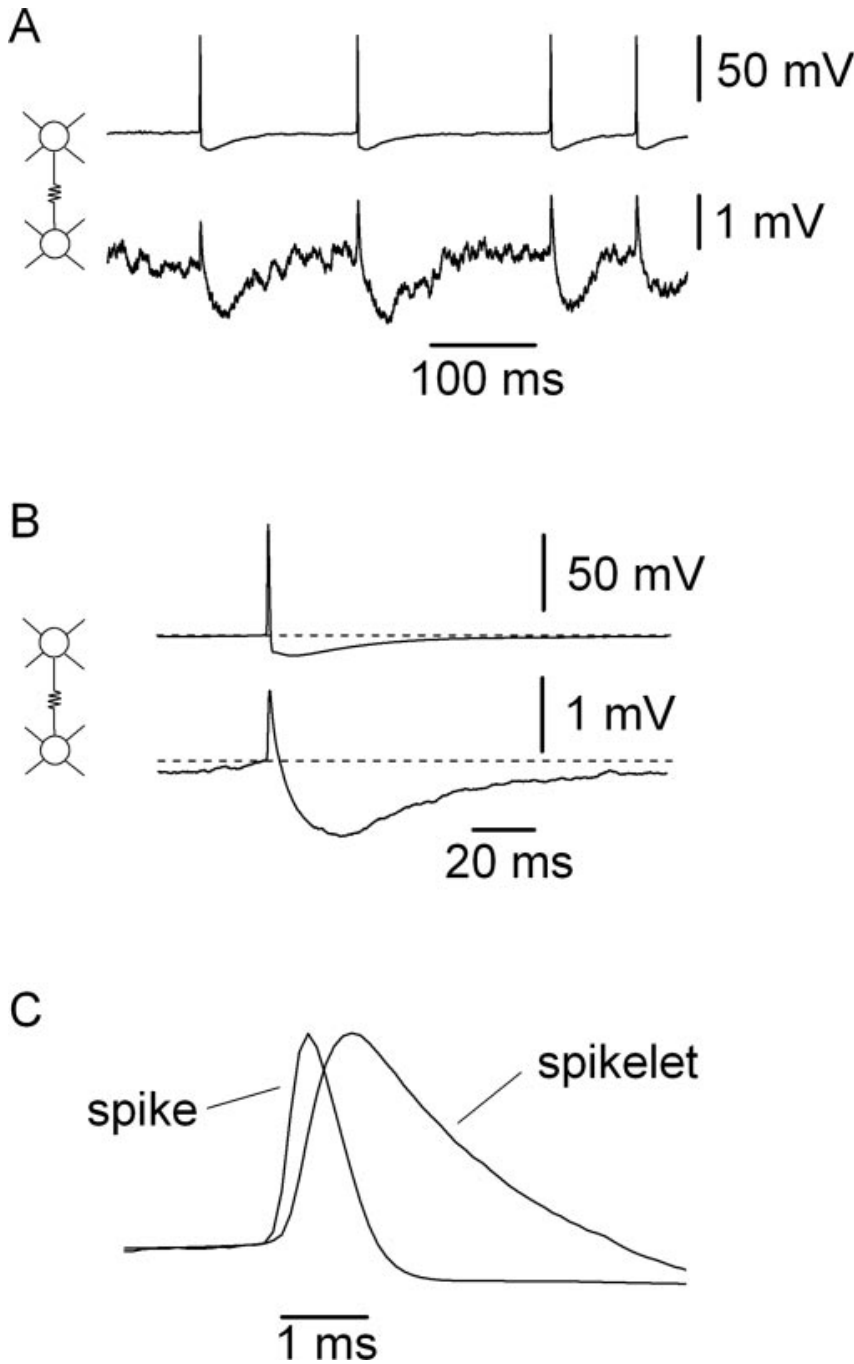

Figure 7. Spike transmission between electrically coupled $C_{1}-1 S$ cells. $A$, Paired recording from two electrically coupled $C_{1}-1 S$ cells. Spikes produced in one of the cells by sustained depolarizing current injection generated biphasic responses in the second cell $\left(V_{\mathrm{m}}=-44\right.$ and $-74 \mathrm{mV}$ for the top and bottom traces, respectively). The coupling coefficient was $9.8 \%$. $B$, Average of 45 traces aligned at the peak of the spike. Data from the same pair as in $A$. Note the fast depolarizing component of the spikelet followed by a slow hyperpolarization, reflecting the presynaptic AHP.C, The presynaptic spike and the postsynaptic spikelet from $B$ are shown scaled and superimposed to facilitate the comparison of their time course.

lation of VIP-containing bipolar interneurons of the rat somatosensory cortex (Cauli et al., 1997; Porter et al., 1998; Cauli et al., 2000). In contrast with $\mathrm{CB}_{1}$-IS cells, which are multipolar or bitufted and have a wide horizontal axonal arborization (Figs. 4, 5), VIP-containing IS cells were characterized by a bipolar cell body and very narrow vertically oriented dendritic and axonal trees. This suggests that IS cells are heterogeneous, and $\mathrm{CB}_{1}$-IS are different from VIP bipolar interneurons. Furthermore, some CCK-containing interneurons in the hippocampus exhibited a firing pattern that may resemble the one described here for $\mathrm{CB}_{1}$-IS cells [Pawelzik et al. (2002), their Figs. 7, 8 E, 9]. Additional studies are necessary to establish whether neocortical $\mathrm{CB}_{1}$-IS cells correspond to the presumed $\mathrm{CB}_{1}$-containing neurons described as regular spiking in the hippocampus (Wilson and Nicoll, 2001, 2002) or whether they represent two different populations of $\mathrm{CB}_{1}$-containing cells. In any case, we believe that the term "regular spiking," also used to describe the firing of pyramidal cells (McCormick et al., 1985), can be confusing when

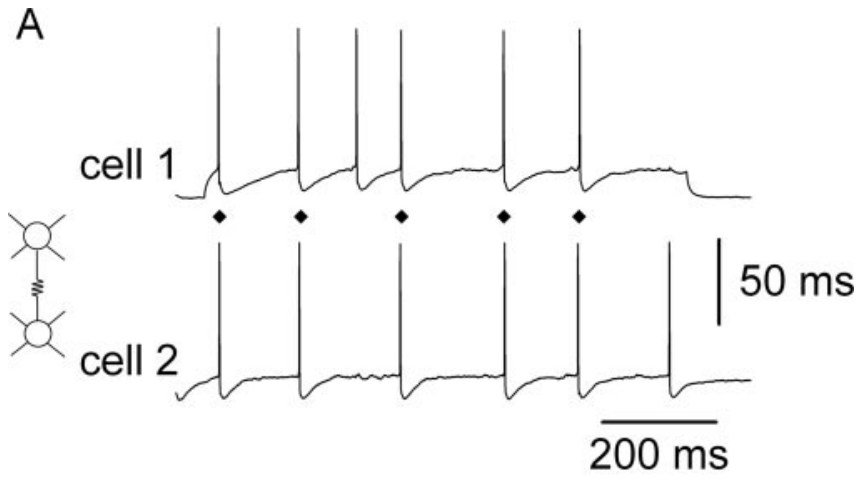

B

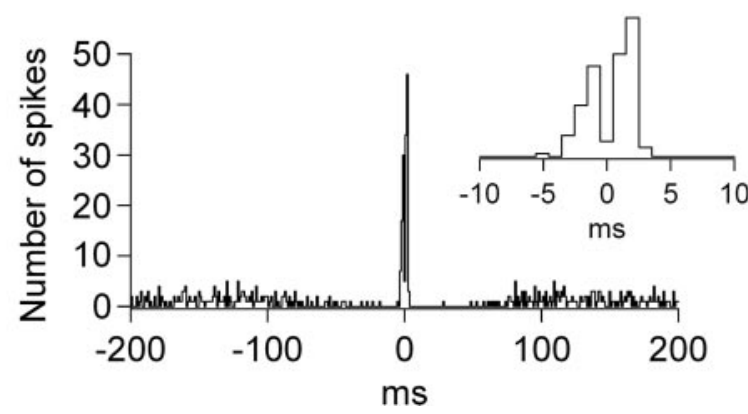

Figure 8. Electrical coupling coordinates the firing of $C_{1} B_{1}-I S$ cells. $A$, Simultaneous recording from a pair of $\mathrm{CB}_{1}-\mathrm{IS}$ cells depolarized to near threshold (average action potential frequencies were 7.6 and $7.3 \mathrm{~Hz}$ ). Diamonds indicate spikes occurring in both cells within a window of $\leq 5$ msec. The coupling coefficient was $9.8 \%$. B, Cross-correlogram of the cells shown in $A$. The bin size is $1 \mathrm{msec}$. The probability of spikes is increased near 0 msec delay. The inset shows the central area of the cross-correlogram at an expanded time scale, with two peaks at $\pm 1-2 \mathrm{msec}$.

used to describe noncategorized interneurons (Kawaguchi, 1995).

Immunohistochemical studies indicate that the expression of $\mathrm{CB}_{1}$ receptors in the cerebral cortex is present in a population of CCK-containing interneurons (Katona et al., 1999, 2000; Tsou et al., 1999; Bodor et al., 2003). CCK-expressing cells have been shown to be heterogeneous, including subpopulations with different morphology, electrophysiology, and expression of neuropeptides and calcium-binding proteins (Kubota and Kawaguchi, 1997; Cope et al., 2002; Kawaguchi and Kondo, 2002; Pawelzik et al., 2002; Losonczy et al., 2004). Thus, small CCKcontaining neocortical cells are usually positive for VIP and calretinin (Kawaguchi and Kondo, 2002) but lack $\mathrm{CB}_{1}$ expression (Bodor et al., 2003). In contrast, large CCK-containing basket neurons are generally negative for VIP and calretinin (Kawaguchi and Kondo, 2002) but express $\mathrm{CB}_{1}$ receptors (Bodor et al., 2003). We suggest that $\mathrm{CB}_{1}$-IS cells may include large CCK-positive cells (Kubota and Kawaguchi, 1997). Interestingly, $\mathrm{CB}_{1}$ expression has also been reported in a population of calbindin-expressing neurons (Marsicano and Lutz, 1999; Tsou et al., 1999; Bodor et al., 2003). Additional experiments are necessary to determine whether other interneuron populations, in addition to $\mathrm{CB}_{1}$-IS cells, express functional $\mathrm{CB}_{1}$ receptors in the cerebral cortex.

Recent reports have proposed that electrical synapses connect GABAergic interneurons belonging to the same class, establishing functional networks embedded within the neocortex. Thus, parvalbumin-expressing FS cells, which account for $\sim 50 \%$ of the total number of GABAergic cells in the neocortex, are highly coupled to other parvalbumin-FS cells but only very rarely coupled to other types of GABAergic interneurons (Galarreta and Hestrin, 1999; Gibson et al., 1999). Similarly, somatostatin- 


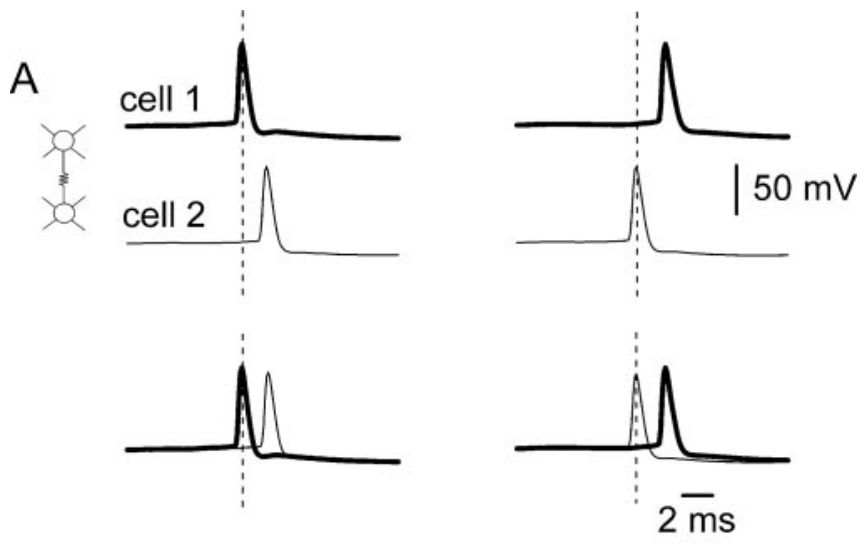

B
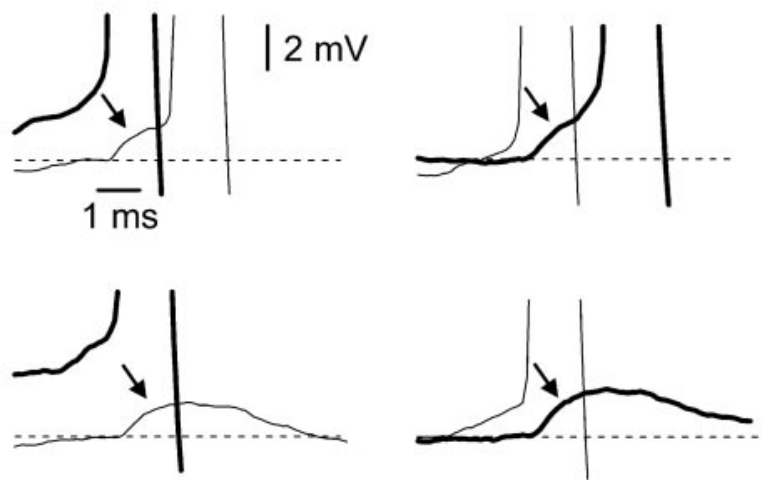

Figure 9. Coherent firing among electrically coupled $C B_{1}-1 S$ cells is mediated by spikelets. $A$, Paired recording from two electrically coupled $C B_{1}-I S$ cells. Two examples of coordinated firing are shown. 0 n the left, the spiking in cell 1 (thick line) precedes the firing in cell 2 (thin line) by $1.6 \mathrm{msec}$. Both traces are superimposed in the bottom. On the right, the firing in cell 2 precedes the spike in cell 1 by $1.9 \mathrm{msec}$. $B$, Top panels show data from $A$ at an expanded voltage scale. The arrows point to the spikelet. Bottom panels show data from examples in which the spikelet in the postsynaptic cell did not reach spike threshold.

expressing LTS cells are highly coupled among themselves but only exceptionally to parvalbumin-FS cells (Gibson et al., 1999). More recently, another network of multipolar-bursting cells expressing calbindin and parvalbumin has been described (Blatow et al., 2003). Multipolar bursting cells are strongly coupled to other multipolar bursting cells but not to parvalbumin-FS cells. Likewise, in layer I, neurogliaform-LS cells were highly coupled via electrical synapses among themselves but not to other interneurons exhibiting different patterns of firing (Chu et al., 2003). In addition, other studies have reported electrical coupling between pairs of similar GABAergic interneurons, including, bipolar, fusiform, and regular-spiking nonpyramidal cells (Tamás et al., 2000; Venance et al., 2000; Szabadics et al., 2001). The high rate of electrical coupling among $\mathrm{CB}_{1}$-IS cells reported here (90\%) suggests that these cells establish a distinct network of GABAergic interneurons. Altogether, cumulative evidence including our results indicates that electrical synapses are formed between functionally similar GABAergic interneurons.

\section{Functional implications}

Electrical coupling among GABAergic interneurons has been shown to promote the coordinated firing of connected cells, contributing to the generation of rhythmic synchronous activity. A wide range of frequencies of oscillatory rhythmic activity has been observed in the neocortex, and it has been proposed that specific GABAergic cells underlie the different types of synchro- nous oscillations (Buhl et al., 1998; Galarreta and Hestrin, 1999; Beierlein et al., 2000; Szabadics et al., 2001; Blatow et al., 2003).

GABAergic interneurons exhibit very heterogeneous physiological properties, and both their intrinsic membrane properties as well as the specific characteristics of their synaptic connections (chemical and electrical) could affect the frequency of the synchronous oscillatory activity they promote (Traub et al., 1996; Wang and Buzsáki, 1996; Beierlein et al., 2000; Tamás et al., 2000; Szabadics et al., 2001; Bartos et al., 2002; Blatow et al., 2003). FS cells are characterized by low input resistance, brief spikes, fast AHPs, and relatively fast IPSCs. The peak of their spikelets typically follows the peak of the presynaptic spike by $\sim 0.3 \mathrm{msec}$, and the minimum value of the hyperpolarizing component of the spikelet reflecting the AHP occurs 4-10 msec after the presynaptic spike (Galarreta and Hestrin, 1999, 2001b, 2002). Relative to FS cells, $\mathrm{CB}_{1}$-IS cells showed higher input resistance, wider action potentials, and slower AHPs. In addition, the peak of the presynaptic spikelet followed the postsynaptic spike peak by $\sim 1 \mathrm{msec}$, and the hyperpolarizing component of the spikelet reached its minimum $\sim 20 \mathrm{msec}$ after the presynaptic spike. These differences suggest that $\mathrm{CB}_{1}$-IS cells may synchronize their activity at lower frequencies than FS cells. However, more experiments are necessary to examine the interaction among $\mathrm{CB}_{1}$-IS cells and how this network orchestrate the activity of other neocortical populations.

By acting presynaptically on GABAergic interneurons expressing $\mathrm{CB}_{1}$ receptors, it has been proposed that endocannabinoids may block GABAergic transmission at specific inputs and could disrupt synchronized oscillations in certain frequency ranges (Katona et al., 2000). Based on our results, it seems reasonable to speculate that the activity-dependent release of endocannabinoids could selectively diminish the action of a network of electrically coupled $\mathrm{CB}_{1}$-IS cells. The possible functional consequences of this dynamic change in cortical circuitry remain to be explored.

\section{References}

Bartos M, Vida I, Frotscher M, Meyer A, Monyer H, Geiger JR, Jonas P (2002) Fast synaptic inhibition promotes synchronized gamma oscillations in hippocampal interneuron networks. Proc Natl Acad Sci USA 99:13222-13227.

Beierlein M, Gibson JR, Connors BW (2000) A network of electrically coupled interneurons drives synchronized inhibition in neocortex. Nat Neurosci 3:904-910.

Blatow M, Rozov A, Katona I, Hormuzdi SG, Meyer AH, Whittington MA, Caputi A, Monyer H (2003) A novel network of multipolar bursting interneurons generates theta frequency oscillations in neocortex. Neuron 38:805-817.

Bodor AL, Katona I, Mackie K, Hajos N, Freund TF (2003) Distinct types of interneurons are targeted by endocannabinoids in the rat soomatosensory cortex. Soc Neurosci Abstr 29:578.13.

Brager DH, Luther PW, Erdélyi F, Szabó G, Alger BE (2003) Regulation of exocytosis from single visualized GABAergic boutons in hippocampal slices. J Neurosci 23:10475-10486.

Buhl EH, Tamas G, Fisahn A (1998) Cholinergic activation and tonic excitation induce persistent gamma oscillations in mouse somatosensory cortex in vitro. J Physiol (Lond) 513:117-126.

Cauli B, Audinat E, Lambolez B, Angulo MC, Ropert N, Tsuzuki K, Hestrin S, Rossier J (1997) Molecular and physiological diversity of cortical nonpyramidal cells. J Neurosci 17:3894-3906.

Cauli B, Porter JT, Tsuzuki K, Lambolez B, Rossier J, Quenet B, Audinat E (2000) Classification of fusiform neocortical interneurons based on unsupervised clustering. Proc Natl Acad Sci USA 97:6144-6149.

Chevaleyre V, Castillo PE (2003) Heterosynaptic LTD of hippocampal GABAergic synapses: a novel role of endocannabinoids in regulating excitability. Neuron 38:461-472. 
Chu Z, Galarreta M, Hestrin S (2003) Synaptic interactions of late-spiking neocortical neurons in layer 1. J Neurosci 23:96-102.

Cope DW, Maccaferri G, Marton LF, Roberts JD, Cobden PM, Somogyi P (2002) Cholecystokinin-immunopositive basket and Schaffer collateralassociated interneurones target different domains of pyramidal cells in the CA1 area of the rat hippocampus. Neuroscience 109:63-80.

Deans MR, Gibson JR, Sellitto C, Connors BW, Paul DL (2001) Synchronous activity of inhibitory networks in neocortex requires electrical synapses containing connexin36. Neuron 31:477-485.

Egertova M, Elphick MR (2000) Localisation of cannabinoid receptors in the rat brain using antibodies to the intracellular C-terminal tail of CB. J Comp Neurol 422:159-171.

Erdélyi F, Sekerkova G, Katarova Z, Hájos N, Palhalmi J, Freund TF, Mugnaini E, Szabó G (2002) GAD65-GFP transgenic mice expressing GFP in the GABAergic nervous system. FENS Abstr 1:AO11-AO13.

Galarreta M, Hestrin S (1999) A network of fast-spiking cells in the neocortex connected by electrical synapses. Nature 402:72-75.

Galarreta M, Hestrin S (2001a) Electrical synapses between GABA-releasing interneurons. Nat Rev Neurosci 2:425-433.

Galarreta M, Hestrin S (2001b) Spike transmission and synchrony detection in networks of GABAergic interneurons. Science 292:2295-2299.

Galarreta M, Hestrin S (2002) Electrical and chemical synapses among parvalbumin fast-spiking GABAergic interneurons in adult mouse neocortex. Proc Natl Acad Sci USA 99:12438-12443.

Gerdeman GL, Ronesi J, Lovinger DM (2002) Postsynaptic endocannabinoid release is critical to long-term depression in the striatum. Nat Neurosci 5:446-451.

Gibson JR, Beierlein M, Connors BW (1999) Two networks of electrically coupled inhibitory neurons in neocortex. Nature 402:75-79.

Hájos N, Katona I, Naiem SS, MacKie K, Ledent C, Mody I, Freund TF (2000) Cannabinoids inhibit hippocampal GABAergic transmission and network oscillations. Eur J Neurosci 12:3239-3249.

Hoffman AF, Lupica CR (2000) Mechanisms of cannabinoid inhibition of $\mathrm{GABA}_{\mathrm{A}}$ synaptic transmission in the hippocampus. J Neurosci 20:2470-2479.

Hormuzdi SG, Pais I, LeBeau FE, Towers SK, Rozov A, Buhl EH, Whittington MA, Monyer H (2001) Impaired electrical signaling disrupts gamma frequency oscillations in connexin 36-deficient mice. Neuron 31:487-495.

Katona I, Sperlágh B, Sík A, Käfalvi A, Vizi ES, Mackie K, Freund TF (1999) Presynaptically located $\mathrm{CB}_{1}$ cannabinoid receptors regulate $\mathrm{GABA}$ release from axon terminals of specific hippocampal interneurons. J Neurosci 19:4544-4558.

Katona I, Sperlágh B, Maglóczky Z, Sántha E, Köfalvi A, Czirják S, Mackie K, Vizi ES, Freund TF (2000) GABAergic interneurons are the targets of cannabinoid actions in the human hippocampus. Neuroscience 100:797-804.

Kawaguchi Y (1993) Groupings of nonpyramidal and pyramidal cells with specific physiological and morphological characteristics in rat frontal cortex. J Neurophysiol 69:416-431.

Kawaguchi Y (1995) Physiological subgroups of nonpyramidal cells with specific morphological characteristics in layer II/III of rat frontal cortex. J Neurosci 15:2638-2655.

Kawaguchi Y, Kondo S (2002) Parvalbumin, somatostatin and cholecystokinin as chemical markers for specific GABAergic interneuron types in the rat frontal cortex. J Neurocytol 31:277-287.

Kawaguchi Y, Kubota Y (1997) GABAergic cell subtypes and their synaptic connections in rat frontal cortex. Cereb Cortex 7:476-486.

Kreitzer AC, Regehr WG (2001) Cerebellar depolarization-induced suppression of inhibition is mediated by endogenous cannabinoids. J Neurosci 21:RC174(1-5).

Kubota Y, Kawaguchi Y (1997) Two distinct subgroups of cholecystokininimmunoreactive cortical interneurons. Brain Res 752:175-183.

Llano I, Leresche N, Marty A (1991) Calcium entry increases the sensitivity of cerebellar Purkinje cells to applied GABA and decreases inhibitory synaptic currents. Neuron 6:565-574.

Long MA, Connors BW (2004) Electrical synapses in the mammalian brain. Annu Rev Neurosci 27:393-418.
López-Bendito G, Sturgess K, Erdélyi F, Szabó G, Molnár Z, Paulsen O (2004) Preferential origin and layer destination of GAD65-GFP cortical interneurons. Cereb Cortex 14:1122-1133.

Losonczy A, Biro AA, Nusser Z (2004) Persistently active cannabinoid receptors mute a subpopulation of hippocampal interneurons. Proc Natl Acad Sci USA 101:1362-1367.

Marsicano G, Lutz B (1999) Expression of the cannabinoid receptor CB1 in distinct neuronal subpopulations in the adult mouse forebrain. Eur J Neurosci 11:4213-4225.

Matsuda LA, Lolait SJ, Brownstein MJ, Young AC, Bonner TI (1990) Structure of a cannabinoid receptor and functional expression of the cloned cDNA. Nature 346:561-564.

McCormick DA, Connors BW, Lighthall JW, Prince DA (1985) Comparative electrophysiology of pyramidal and sparsely spiny stellate neurons of the neocortex. J Neurophysiol 54:782-806.

Ohno-Shosaku T, Maejima T, Kano M (2001) Endogenous cannabinoids mediate retrograde signals from depolarized postsynaptic neurons to presynaptic terminals. Neuron 29:729-738.

Pawelzik H, Hughes DI, Thomson AM (2002) Physiological and morphological diversity of immunocytochemically defined parvalbumin- and cholecystokinin-positive interneurones in CA1 of the adult rat hippocampus. J Comp Neurol 443:346-367.

Piomelli D (2003) The molecular logic of endocannabinoid signalling. Nat Rev Neurosci 4:873-884.

Pitler TA, Alger BE (1992) Postsynaptic spike firing reduces synaptic $\mathrm{GABA}_{\mathrm{A}}$ responses in hippocampal pyramidal cells. J Neurosci 12:4122-4132.

Porter JT, Cauli B, Staiger JF, Lambolez B, Rossier J, Audinat E (1998) Properties of bipolar VIPergic interneurons and their excitation by pyramidal neurons in the rat neocortex. Eur J Neurosci 10:3617-3628.

Stuart GJ, Dodt HU, Sakmann B (1993) Patch-clamp recordings from the soma and dendrites of neurons in brain slices using infrared video microscopy. Pflügers Arch 423:511-518.

Szabadics J, Lorincz A, Tamás G (2001) Beta and gamma frequency synchronization by dendritic gabaergic synapses and gap junctions in a network of cortical interneurons. J Neurosci 21:5824-5831.

Tamás G, Buhl EH, Lorincz A, Somogyi P (2000) Proximally targeted GABAergic synapses and gap junctions synchronize cortical interneurons. Nat Neurosci 3:366-371.

Traub RD, Whittington MA, Colling SB, Buzsáki G, Jefferys JG (1996) Analysis of gamma rhythms in the rat hippocampus in vitro and in vivo. J Physiol (Lond) 493:471-484.

Trettel J, Levine ES (2002) Cannabinoids depress inhibitory synaptic inputs received by layer $2 / 3$ pyramidal neurons of the neocortex. J Neurophysiol 88:534-539.

Trettel J, Levine ES (2003) Endocannabinoids mediate rapid retrograde signaling at interneuron right-arrow pyramidal neuron synapses of the neocortex. J Neurophysiol 89:2334-2338.

Trettel J, Fortin DA, Levine ES (2004) Endocannabinoid signalling selectively targets perisomatic inhibitory inputs to pyramidal neurones in juvenile mouse neocortex. J Physiol (Lond) 556:95-107.

Tsou K, Mackie K, Sañudo-Peña MC, Walker JM (1999) Cannabinoid CB1 receptors are localized primarily on cholecystokinin-containing GABAergic interneurons in the rat hippocampal formation. Neuroscience 93:969-975.

Venance L, Rozov A, Blatow M, Burnashev N, Feldmeyer D, Monyer H (2000) Connexin expression in electrically coupled postnatal rat brain neurons. Proc Natl Acad Sci USA 97:10260-10265.

Wang XJ, Buzsáki G (1996) Gamma oscillation by synaptic inhibition in a hippocampal interneuronal network model. J Neurosci 16:6402-6413.

Wilson RI, Nicoll RA (2001) Endogenous cannabinoids mediate retrograde signalling at hippocampal synapses. Nature 410:588-592.

Wilson RI, Nicoll RA (2002) Endocannabinoid signaling in the brain. Science 296:678-682.

Wilson RI, Kunos G, Nicoll RA (2001) Presynaptic specificity of endocannabinoid signaling in the hippocampus. Neuron 31:453-462. 